\title{
Prevalensi dan Dampak Kecanduan Gadget Pada Remaja: Literature Review
}

\author{
Mentari Kusuma Rini ${ }^{1}$, Titih Huriah ${ }^{2}$ \\ ${ }^{1}$ Magister Keperawatan, Program Pascasarjana. Universitas Muhammadiyah Yogyakarta \\ 2 Dosen, Magister Keperawatan Program Pascasarjana. Universitas Muhammadiyah Yogyakarta
}

\begin{tabular}{|c|c|}
\hline INFORMASI & ABSTRACT \\
\hline $\begin{array}{l}\text { Korespondensi: } \\
\text { mentarokr@gmail.com }\end{array}$ & $\begin{array}{l}\text { Objective: To know the prevalence and impact of gadgets addiction on youth. } \\
\text { Method: The method utilized in this paper was a literature review of internation- } \\
\text { al journals conducted using the PubMed, ProQuest, Goggle Scholar database. At } \\
\text { the initial stage of the search with the keywords: "((prevalence AND impact AND } \\
\text { smartphone addiction OR internet addiction] AND adolescent))" it gained } 14 \text { inter- } \\
\text { national articles from the range of } 2016 \text { to } 2018 \text { which were in accordance with the } \\
\text { inclusion and exclusion criteria. }\end{array}$ \\
\hline $\begin{array}{l}\text { Keywords: } \\
\text { Gadgets, Internet, Addic- } \\
\text { tion, Youth }\end{array}$ & $\begin{array}{l}\text { Results: From the } 14 \text { articles, there were } 6 \text { articles that discussed the prevalence of } \\
\text { internet addiction } 2 \text { of which occurred in developed countries such as Japan and } \\
\text { Taiwan, from the two countries the prevalence of internet addiction was 22.6\% on } \\
\text { average. Meanwhile, the prevalence in developing countries such as Turkey, Tunisia, } \\
\text { China and India averaged } 32.3 \% \text {. Eight articles reviewed the effects of internet ad- } \\
\text { diction. The impacts of using gadgets can be seen physically (Obesity) and psycholog- } \\
\text { ically [Depression, loneliness, suicide, sleep disturbance, attention deficit disorder and } \\
\text { hyperactivity] and other impacts such as family dysfunction. } \\
\text { Conclusion: The review of this literature review has gained the different prevalence of } \\
\text { gadget and internet addiction between developed and developing countries in which } \\
\text { the developed countries was } 22.6 \% \text { while developing countries was 32.3\%. The im- } \\
\text { pacts given of this addiction were the physical, psychological and family function } \\
\text { impacts. }\end{array}$ \\
\hline
\end{tabular}




\section{PENDAHULUAN}

Perkembangan media eletronik terjadi begitu pesat, seperti bermunculannya berbagai macam bentuk dan kegunaan gadget. Pengguna gadget tidak hanya berasal dari kalangan anak muda dan dewasa saja tetapi anak-anak usia dinipun sudah mulai terpapar dengan penggunaan gadget. Hal ini mengundang perhatian dari berbagai pihak, dikarenakan anak-anak yang sudah mulai terpapar oleh gadget seringkali memiliki dampak negatif dari segi tumbuh kembangnya (Diarti and Sutriningsih, 2017)

Kecanduan gadget maupun internet merupakan penggunaan secara berlebihan yang mengganggu kehidupan sehari-hari penggunanya, biasanya mengakibatkan keasyikan dan cenderung apatis terhadap sekitar dan sering kali marah apabila ada seseorang yang mengganggunya.Kecanduan gadget dan internet tidak hanya terjadi di Indonesia tetapi di seluruh dunia. Berdasarkan survei meta analisis kecanduan internet tertinggi terjadi di Timur Tengah (10.9\%), kemudian Amerika Utara (8,0\%) dan Asia $(7,1 \%)$. Pada remaja Asia khususnya di China tingkat kecanduan internet yaitu 2,2- 9,6\%, Jepang 3,1-6,2\%, Filifina 4,9-21,1\%, dan Hong Kong 3,016,4\% (Lau et al., 2017).

Di Indonesia sendiri penggunaan gadget didominasi oleh remaja. Badan Pusat Statistik (BPS) bekerjasama dengan Asosiasi Penyelenggara Jasa Internet Indonesia (APJII) mencatat angka pertumbuhan pengguna internet di Indonesia hingga akhir tahun 2013 mencapai 71,19 juta orang, meningkat pada tahun 2014 mencapai 83,7 juta orang (Diarti and Sutriningsih, 2017)

Saputra (2016) menyebutkan di Indonesia kecanduan internet pada remaja sebesar 42,4\%.Pada kesuluruhan remaja yang menggunakan internet, $70 \%$ diantaranya menggakses internet untuk halhal negatif seperti cybercrime, cyberporn, dan game online lebih dari 3 jam perhari. Kecanduan internet juga dapat menimbulkan permasalahan fisik seperti mata kering, nyeri punggung dikarenakan terlalu lama duduk di depan komputer, kebersihan yang terabaikan dan gangguan pola tidur. masalah psikologis dan sosial seperti: penurunan daya ingat, euforia saat online, waktu berinternet berlebihan, menarik diri dari lingkungan sosial, merasa cemas dan depresi bila offline (Maulida and Sari, n.d.).

Pada pembahasan ini mempertimbangkan literature tentang topik tersebut dengan pencarian terstruktur. Tujuan dari penulisan adalah untuk mengetahuiprevalensi dan dampak kecanduan gadget pada remaja.

\section{METODE}

Metode yang digunakan adalah literatur review dengan mencari artikel di database PubMed, Proquest, Goggle Scholar. Pada tahap awal pencarian dengan keywords: "((prevalence AND impactAND (smartphone addiction OR internet addiction) AND adolencent))" didapatkan hasil 15artikel internasionaldari rentang tahun 2016 sampai 2018 yang sesuai dengan kriteria inklusi dan eksklusi.

Kriteria inklusi berikut digunakan untuk pemilihan studi untuk literature review ini : 1) Penelitian berkaitan dengan dampak dan prevalensi terhadap kecanduan pada gadgetdan 2) Penelitian ini memberikan informasi tentangdampak dan prevalensi terhadap kecanduan pada gadget. Kriteria eksklusi dalam penulisan ini adalah : 1) Publikasi artikel hanya menampilkan abstrak saja dan 2) Artikel yang tidak jelas akan di periksa dan dievaluasi dari semua publikasi yang diambil.

Jumlah artikel yang ditemukan adalah 8,574 artikel kemudian didentifikasi untuk judul dan abstrak 8,551 artikel tidak disertakan karena tidak sesuai dengan topik. Hasil seleksi tersisa 23 artikel kemudian di review secara penuh. Setelah direview terdapat 9 artikel yang tidak memenuhi kriteria inklusi. Artikel dan langkah akhir yang sesuai dengan kriteria inklusi sebanyak 14 artikel. 


\section{HASIL}

Fokus utama dari literatur review ini adalah prevalensi dan dampak dari kecanduan gadget. Untuk mengoptimalkan interpretasi ini, pertamatama review akan mengklarifikasi hasil temuan dari beberapa penelitian.

Tabel 1. Proses Pencarian Artikel

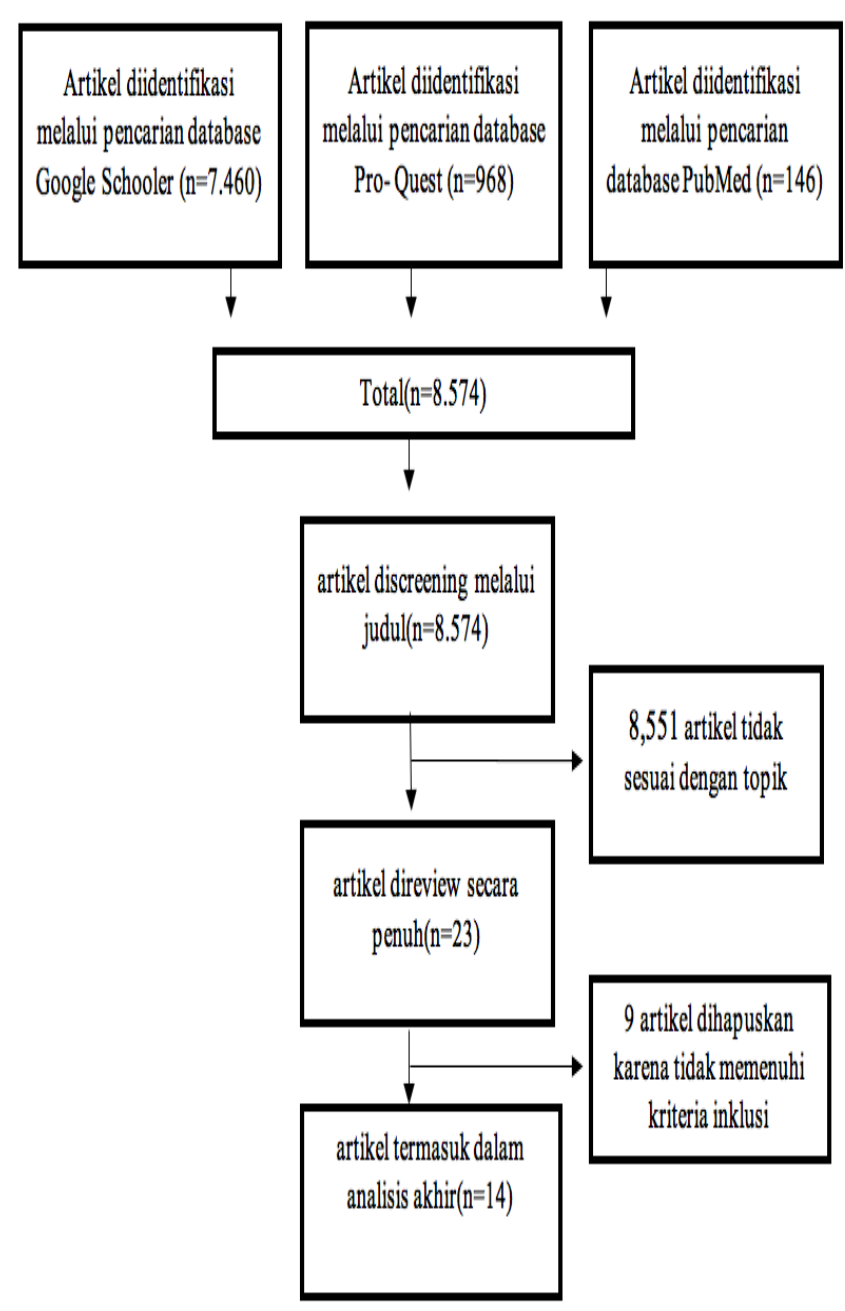

\section{Responden}

Artikel penelitian yang digunakan merupakan artikel yang dilakukan di berbagai macam Negara seperti: Turki, Korea Selatan, Jepang, Taiwan, Iran, Tunisia, Nepal, Switzerland, Inggris, China, India dan Indonesia. Beberapa artikel yang telah di dapat yaitu sebanyak 14artikel, mayoritas responden penelitian adalah remaja.

Hasil tinjauan dari 14 artikel tersebut rata-rata usia responden yaitu, dibawah 18 tahun terdapatdalam 8 artikel, sedangkan yang berusia diatas 18 tahun atau lebih terdapat di dalam3 artikel dan sisanya tidak disebutkan usia responden. Pada 14 artikel tersebut jenis kelamin responden yang digunakan pada keseluruhan penelitian menggunakan keduanyayaitu laki-laki dan perempuan. Untuk status pendidikan responden pada penelitian ini 4 artikel menyebutkan responden adalah pelajar dan 4 artikel lain menyebutkan responden adalah mahasiswa perguruan tinggi, sedangkan 6 artikel sisanya tidak menyebutkan status pendidikan responden.

\section{Prevalensi kecanduan Internet dan gadget}

Prevalensi kecanduan internet di dunia mencapai 6\% (182 juta orang) dari populasi di dunia. Penelitian yang dilakukan di Universitas of Hongkong, memilih 80 studi global meliputi laporan kecanduan internet di 31 Negara. Sebanyak 544 responden disurvei dengan 49\% laki-laki berusia 18-24 tahun. Hasil survei menunjukkan, tingkat prevalensi kecanduan internet di 31 Negara rata-rata 6\%. Masalah kecanduan internet terbesar ditemukan di Timur Tengah dengan presentase 10,9\% (Maulida and Sari, 2017).

Pada 6 artikel yang telah direview membahas prevalensi kecanduan internet dari berbagai macam negara, yaitunegara maju maupun negara berkembang. Pada negara maju yang di wakiliki oleh Asia seperti Jepang, (So et al., 2017) memaparkan bahwa dari 132 remaja 43,3\% diantaranya mengalami kecanduan internet. 
Tabel 2. Studi Karakteristik

\begin{tabular}{|c|c|c|c|c|c|}
\hline No & Penulis & Tujuan & Jenis Penelitian & Responden & Hasil \\
\hline 1 & $\begin{array}{l}\text { (Gunay et al., } \\
\text { 2018a) }\end{array}$ & $\begin{array}{l}\text { Untuk menentukan kecanduan } \\
\text { internet dan tingkat depresi } \\
\text { pada mahasiswa. efek dari be- } \\
\text { berapa faktor sosial demografis } \\
\text { pada tingkat ini dan hubungan } \\
\text { antara kecanduan internet dan } \\
\text { gejala depresi }\end{array}$ & $\begin{array}{l}\text { Kuantitatif (de- } \\
\text { scriptive) }\end{array}$ & $\begin{array}{l}1.288 \text { mahasiswa di- } \\
\text { antaranya: Mahasiswa } \\
\text { kedoteran, teknik, } \\
\text { ekonomi dan admin- } \\
\text { istrasi }\end{array}$ & $\begin{array}{l}\text { Gejala depresi ditemukan pada } 26,4 \% \text { mahsiswa, kecanduan internet } 0.2 \% \text { dan gejala } \\
\text { terbatas pada kecanduan internet } 75 \% \text {. Scor intrenet addiction scale (IAS) meingkat dian- } \\
\text { tara laki-laki dan beck depression inventory }(\mathrm{BDI}) \text { meningkat diantara perempuan korelasi } \\
\text { signifikan antara IAS dan BDI }(\mathrm{r}=0.325, \mathrm{p}<0.001) \text {. }\end{array}$ \\
\hline 2. & (Wu et al., 2019a) & $\begin{array}{l}\text { Untuk menyelidiki prevalensi } \\
\text { dan hubungan psikologi dari } \\
\text { gangguan kecanduan internet }\end{array}$ & $\begin{array}{l}\text { Kuantitatif (sur- } \\
\text { vey) }\end{array}$ & $\begin{array}{l}2.147 \text { responden } \\
\text { (penduduk taiwan) } \\
\text { usia rata-rata } 15 \text { ta- } \\
\text { hun atau lebih }\end{array}$ & $\begin{array}{l}\text { Diantara } 2.147 \text { responden, } 50,4 \% \text { perempuan. Prevalensi internet addictive disorder } \\
\text { (IAD) untuk satu tahun sebanyak 1,9\% (1,2 untuk internet gaming disorder dan } 0,7 \% \\
\text { untuk IAD nongame). Orang dengan IAD dikarakteritikan sebagai: lebih muda, pen- } \\
\text { gangguran ataupun pelajar, yang mengalami tekanan psikologis dan terlibat dalam akti- } \\
\text { vitas online rutin (game, menonton video dan belanja) }\end{array}$ \\
\hline 3. & $\begin{array}{l}\text { (Parashkouh et al., } \\
\text { 2018) }\end{array}$ & $\begin{array}{l}\text { Untuk menilai kecanduan } \\
\text { internet dan handphone dan } \\
\text { hubungan dengan kesepian } \\
\text { pada remaja di Iran. }\end{array}$ & $\begin{array}{l}\text { Kuantitatif (cros- } \\
\text { sectional dan an- } \\
\text { alytic study) }\end{array}$ & $\begin{array}{l}518 \text { responden. La- } \\
\text { ki-laki } 270 \text {, perem- } \\
\text { puan } 311 .\end{array}$ & $\begin{array}{l}\text { Sekitar } 49 \% \text { dari peserta menyatakan bahwa mereka menghabisakan sebagian waktu } \\
\text { luang dengan teman-temannya dan memiliki sekitar } 6 \text { teman dekat. } 76 \% \text { dari peserta } \\
\text { mengatakan bahwa mereka menggunakan ponsel secara teratur. Responden mengatakan } \\
\text { penggunaan internet/handphone untuk mengirimkan pesan }(31,7 \%) \text { menyambungkan } \\
\text { ke internet }(23,9 \%) \text { dan untuk bercakap-cakap } 13,3 \% \text {. Responden juga mengatakan } \\
\text { bahwa mereka menggunakan internet untuk mendowload musik/ film / buku } 68 \% \text { dan } \\
\text { terlibat dan sosial media sekitar } 36,1 \%\end{array}$ \\
\hline 4. & (Mellouli et al., n.d.) & $\begin{array}{l}\text { Bertujuan untuk menentukan } \\
\text { prevalensi kecanduan internet } \\
\text { di kalangan mahasiswa dan } \\
\text { prediktornya di wilayah Sousse, } \\
\text { Tunisia }\end{array}$ & $\begin{array}{l}\text { Kuantitatif (cross } \\
\text { sectional) }\end{array}$ & $\begin{array}{l}556 \text { siswa dari } 5 \text { per- } \\
\text { guruan tinggi yang } \\
\text { dipilih secara acak }\end{array}$ & $\begin{array}{l}\text { Tingkat respon sebanyak } 96 \% \text {. usia rata-rata peserta adalah } 21.8 \pm 2.2 \text { tahun. Wanita } \\
\text { mewakili } 51,8 \% \text { dari mereka. Kontrol penggunaan internet yang buruk ditemukan di } \\
\text { antara } 280(54,0 \% \text {; } 95 \% \text { CI } 49,7 \%, 58,3) \text { peserta. Tingkat pendidikan yang rendah di } \\
\text { antara orang tua, usia muda, penggunaan tembakau seumur hidup, dan penggunaan } \\
\text { obat-obatan seumur hidup secara signifikan terkait dengan kontrol yang buruk terhadap } \\
\text { penggunaan internet di kalangan siswa }(\mathrm{P}<0,0001) \text {. Sementara itu, faktor yang paling } \\
\text { berpengaruh pada penggunaan internet di anatara mereka adalah kelulusan dengan rasio } \\
\text { odds yang disesuaikan dari } 2,4(95 \% \mathrm{CI}: 1,73,6)\end{array}$ \\
\hline
\end{tabular}




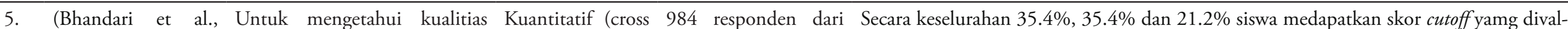

2017a) tidur, kecanduan internet dan sectional) tanda gejala depresi diantara mahasiswa sarjana di Nepal s
27 kampus sarjaan di idasi untuk masing-masing kecanduan internet dankualitias tidur yang buruk. Kualitas Chitwan dan Kath- tidur yang buruk dikaitkan dengan usia yang lebih rendah, tidak mengkonsumsi alkohol, manduan Nepal. menjadi penganut Hindu, aktif secara seksual dan gagl dalam ujian tahun-tahun sebelumnya. Kecanduan internet lebih banyak dikaitkan dengan usia yang lebih rendah, tidak aktif secara seksual, gagal dalam ujian tahun sebelumnya. Kecanduan internet memediasi secara statistic 16,5\% dari pengaruh tidak langsung dari gejala depresi. Kualitas tidur disisi lain memediasi kecanduan 30,9\% dari efek tidak langsung dari kecanduan intermet dari gejala depresi.

\begin{tabular}{|c|c|c|c|c|c|}
\hline 6. & $\begin{array}{l}\text { (Eliacik et al., } \\
\text { 2016a) }\end{array}$ & $\begin{array}{l}\text { Untuk menentukan hubungan } \\
\text { antara kecanduan internet dan } \\
\text { masalah terkait obesitas pada } \\
\text { remaja. }\end{array}$ & $\begin{array}{l}\text { Kuantitatif (cross } \\
\text { sectional) }\end{array}$ & $\begin{array}{l}71 \text { responden dengan } \\
\text { obesitas }\end{array}$ & $\begin{array}{l}\text { Dalam kelompok obesitas } 47,8 \%(n-34) \text { peserta menderita kecanduan internet diband- } \\
\text { ingkan dengan } 21,8 \% \text { (14) dalam kelompok kontrol. }\end{array}$ \\
\hline 7. & $\begin{array}{l}\text { (Pan and Yeh, } \\
2018 \mathrm{a})\end{array}$ & $\begin{array}{l}\text { Untuk mengetahui peran } \\
\text { kecanduan internet dalam } \\
\text { perkembangan prilaku bunuh } \\
\text { diri pada remaja selama } 1 \text { ta- } \\
\text { hun. }\end{array}$ & Kuantitatif & $\begin{array}{l}1861 \text { remaja dengan } \\
\text { usia rata-rata } 15 \text { ta- } \\
\text { hun }\end{array}$ & $\begin{array}{l}\text { Dari jumlah responden yang sudah mengikuti alur penelitian dai } 1861,126(6,8 \%) \text { di- } \\
\text { antaranya mengatakan memiliki riwayat prilaku bunuh diri atau melukai dirinya sendiri } \\
\text { dan } 1735(93,2 \%) \text { tidak memiliki riwayat bunuh diri. Dari } 1735 \text { siswa ini, } 1507(1241 \\
\text { pria dan } 266 \text { wanita) }\end{array}$ \\
\hline 8. & $\begin{array}{l}\text { (Panagiotidi and } \\
\text { Overton, 2018a) }\end{array}$ & $\begin{array}{l}\text { Untuk menguji hubungan an- } \\
\text { tara kecanduan internet dan } \\
\text { attention deficit hyperactivity } \\
\text { disorder (ADHD) }\end{array}$ & Kuantitatif & $\begin{array}{l}400 \text { peserta yang be- } \\
\text { rusia } 18-70 \text { tahun } \\
\text { yang telah menyele- } \\
\text { saikan adult ADHD- } \\
\text { selfreport scale } \\
\text { (ASRS), Young's in- } \\
\text { ternet addiction test, } \\
\text { dan aktivitas online } \\
\text { pilihan mereka. }\end{array}$ & $\begin{array}{l}\text { Terdapat hubungan anatara tingkat gejala ADHD yang lebih tinggi dan IA. Predictor } \\
\text { terbaik skol IA adalah gejala ADHD, usia, bermain game online, dan menghabiskan } \\
\text { waktu lebih untuk online. }\end{array}$ \\
\hline 9. & (Seyrek et al., 2017a) & $\begin{array}{l}\text { Untuk melihat prevalen- } \\
\text { si kecanduan internet dan } \\
\text { hubungan antara karakteristik } \\
\text { sosiodemografis, depresi, kece- } \\
\text { masan, gejala gangguan perha- } \\
\text { tian/hiperaktif dan kecanduan } \\
\text { internet pada remaja }\end{array}$ & $\begin{array}{l}\text { Kuantitatif (sross } \\
\text { sectional) }\end{array}$ & $\begin{array}{l}468 \text { responden den- } \\
\text { gan usia } 12-17 \text { tahun }\end{array}$ & $\begin{array}{l}\text { Sekitar } 1,6 \% \text { mengalami kecanduan. Sedangkan } 16,2 \% \text { kemungkinan mengalami ke- } \\
\text { canduan. Ada korelasi yang signifikan antara kecanduan internet dan depresi, kecemasan, } \\
\text { gangguan perhatian, dan gejala hiperaktif pada remaja. Merokok juga dikaitkan dengan } \\
\text { kecanduan internet. Tidak ada hubungan anatara kecanduan internet dengan usia, jenis } \\
\text { kelamin, IMT, jenis sekolah dan status sosial ekonomi. }\end{array}$ \\
\hline
\end{tabular}




\begin{tabular}{|c|c|c|c|c|c|}
\hline 10. & (Xin et al., 2018a) & $\begin{array}{l}\text { Untuk mencari tahu aktivitas } \\
\text { online, prevalensi kecanduan } \\
\text { internet dalam kaitannya den- } \\
\text { gan } \\
\text { karakteristik demografis dan } \\
\text { faktor resiko yang berkaitan } \\
\text { denga keluarga dan sekolah di } \\
\text { kalangan remaja. }\end{array}$ & Kuantitatif & $\begin{array}{l}6468 \text { responden } \\
\text { remaja yang berusia } \\
10-18 \text { tahun yang } \\
\text { diambil dari seko- } \\
\text { lah-sekolah yang ada } \\
\text { di Guangzhou, China }\end{array}$ & $\begin{array}{l}\text { Prevalensi kecanduan internet adalah } 26,50 \% \text {, dengan kecanduan berat } 0,96 \% \text {. Ke- } \\
\text { canduan interenet lebih tinggi terjadi pada laki-laki daripada perempuan }(30,6 \% \text { dan } \\
21,2 \%) \text {. }\end{array}$ \\
\hline 11. & (S. C. and S., 2017a) & $\begin{array}{l}\text { Untuk memperkirakan preva- } \\
\text { lensi kecanduan internet pada } \\
\text { mahasiswa kedokteran tahun } \\
\text { pertama }\end{array}$ & $\begin{array}{l}\text { Kuantitatif (cross } \\
\text { sectional) }\end{array}$ & $\begin{array}{l}\text { Mahasiswa tahun per- } \\
\text { tama yang berjumlah } \\
140 \text { orang. }\end{array}$ & $\begin{array}{l}\text { Dari } 140 \text { subjek penelitian, mayoritas }(73,5 \%) \text { berusia } 18 \text { tahun, } 62,14 \% \text { adalah per- } \\
\text { empuan, } 81(57,86 \%) \text { adalah penghuni asrama. } 77(55 \%) \text { siswa menggunakan interent } \\
\text { selama } 4-6 \text { jam perhari. } 80(57,14 \%) \text { siswa telah telah menggunkan internet selama lebih } \\
\text { dari } 5 \text { tahun. Prevalensi penggunaan internet berdasarkan kuesioner adalah } 66(47,14 \%) \\
\text { dari } 140 \text { responden. }\end{array}$ \\
\hline 12. & $\begin{array}{l}\text { (Chasanah and Ki- } \\
\text { lis, 2018a) }\end{array}$ & $\begin{array}{l}\text { untuk menilai apakah kecan- } \\
\text { duan gadget mempengaruhi } \\
\text { fungsi keluarga remaja dan di- } \\
\text { mensinya. }\end{array}$ & Kuantitatif & $\begin{array}{l}\text { Data dikumpulkan } \\
\text { dari } 226 \text { remaja beru- } \\
\text { sia } 12-18 \text { tahun }\end{array}$ & $\begin{array}{l}\text { Hasil penelitian menunjukkan efek negatif dari kecanduan gadget pada fungsi keluarga } \\
\text { (F }(1.224)=30.796, p<0,001(1 \text {-tailed), } \mathrm{R} 2=0,121) \text {. Hasil dari statistik MANOVA } \\
\text { menunjukkan bahwa ada perbedaan yang signifikan dari enam dimensi fungsi keluarga } \\
\text { antara remaja dengan kecanduan gadget berisiko tinggi dan rendah }(\mathrm{F}(7.218)=4.852 \text {, } \mathrm{p} \\
<0,01 \text { (1-tailed); Wilks ' } \Lambda=0,865 \text {, parsial } \bigotimes 2=0,135) \text {, signifikan pada } \mathrm{p}=0,000-0,006)\end{array}$ \\
\hline 13. & $\begin{array}{l}\text { (Kawabe et al., } \\
\text { 2016) }\end{array}$ & $\begin{array}{l}\text { Untuk melihat apakah kecan- } \\
\text { duan internet mengganggu ke- } \\
\text { hidupan sehari-hari remaja. }\end{array}$ & Kuantitatif & $\begin{array}{l}\text { Siswa sekolah menen- } \\
\text { gah pertama (usia } 12- \\
15 \text { tahun) }\end{array}$ & $\begin{array}{l}\text { Berdasarkan skor total internet addiction test, } 2,0 \% \text { (pria, 2,1\%; wanita, } 1,9 \% \text { ) dan } \\
21,7 \% \text { (pria, 19,8\%; wanita, 23,6\%) dari total } 853 \text { peserta (tingkat respons, 97,6\%) } \\
\text { diklasifikasikan sebagai kecanduan dan mungkin kecanduan, masing-masing. Total skor } \\
\text { General health questionnaire secara signifikan lebih tinggi pada pecandu }(12,97,4) \text { dan } \\
\text { mungkin kelompok yang kecanduan (8,8 6.0) daripada kelompok yang tidak kecanduan } \\
\text { (4.3 4.6; P <0.001, kedua kelompok). }\end{array}$ \\
\hline
\end{tabular}

canduan internet pada remaja sectional) nautism specrtrum dis-

di Jepang dengan gangguan order (ASD) di klinis

spektrum autisme psikiatri Jepang 
(Wu et al., 2019) menyebutkan pada Negara Taiwan terdapat $1,9 \%$ dari 2.147 remaja yang mengalami kecanduan internet. Prevalensi kecanduan internet di negara maju pada artikel ini yaitu rata-rata sebesar $22,6 \%$.

Pada 4 artikel membahas prevalensi di negaraberkembang.Penelitian (Mellouli et al., 2017) melihat kecanduan internet dari Negara Tunisia sebanyak 54\% dari 556 total responden. (Seyrek et al., 2017) meneliti kecanduan internet pada Negara Turki sebanyak 1,6\% dari 468 responden. (S. C. and S., 2017a) menyebutkan di India sebanyak 66 orang $(47,4 \%)$ dari 140 responden mengalami kecanduan internet, sedangkan (Xin et al., 2018) mengatakan di China sebesar 26,5\% diantara 6468 responden mengalami kecanduan internet. Prevalensi kecanduan internet di Negara berkembang pada 4 artikel ini rata-rata sebesar $32,3 \%$.

\section{Dampak kecanduan Internet dan gadget}

Dampak yang ditimbulkan dari penggunaan gadget secara berlebihan pada artikel yang telah direview, yaitu:

\section{Fisik}

Satu diantara 8 artikel yang memaparkan dampak dari kecanduan gadget menjelaskan dampak secara fisik yaitu obesitas (Eliacik et al., 2016). Dalam kelompok obesitas 47,8 \%(n-34) peserta menderita kecanduan internet lebih banyak dibandingkan pada kelompok yang tidak mengalami obesitas 21,8\% (14).

\section{Psikologi}

Lima artikel menyebutkan dampak psikologi seperti depresi. Penelitian (Gunay et al., 2018) melihat dampak gejala depresi dari kecanduan internet. Penelitian yang dilakukan terhadap mahasiswa di Turki sebanyak 1,288 mahasiswa gejala depresi ditemukan pada $26,4 \%$ siswa, sedangkan kecanduan internet $0,2 \%$, terdapat hubungan yang signifikan antara kecanduan internet dan gejala depresi pada mahasiswa. (S. C. and S., 2017) menemukan dam pak lain akibat kecanduan internet ataupun gadget yaitu kesepian, dimana terdapat hubungan antara kecanduan internet dan kesepian pada remaja. Penelitian (Pan and Yeh, 2018) menyoroti dampak bunuh diri yang ditimbulkan dari kecanduan internet. Pada penelitian yang dilakukan di Taiwan, orang yang cenderung memiliki kebiasaan menggunakan internet berlebihan secara prospektif terkait dengan perilaku selfharm atau bunuh diri dibandingkan mereka yang tidak memiliki kecanduan internet. (Panagiotidi and Overton, 2018) mengamati 400 anak yang kecanduan internet dengan perilaku Attention Deficit Hyperactivity Disorder (ADHD), hasil penelitian menunjukkan terdapat hubungan antara tingkat gejala ADHD yang lebih tinggi dan kecanduan internet. (Bhandari et al., 2017) melakukan penelitian pada 984 responden dari 27 kampus sarjana di Chitwan dan Kathmanduan Nepal, hasilnya kecanduan internet yang disebabkan oleh gejala depresi mempengaruhi kualitas tidur sebesar 30\%.

\section{Dampak lain}

Satu artikel membahas dampak lain yang ditimbulkan oleh kecanduan internet yaitu terganggunya fungsi keluarga. Penelitian (Chasanah and Kilis, 2018) menunjukkan efek negatif dari kecanduan gadget pada fungsi keluarga $(\mathrm{F}(1.224)=30.796$, $\mathrm{p}$ $<0,001$ (1-tailed), R2 = 0,121). Hasil dari statistik MANOVA menunjukkan bahwa ada perbedaan yang signifikan dari enam dimensi fungsi keluarga antara remaja dengan kecanduan gadget berisiko tinggi dan rendah $(\mathrm{F}(7.218)=4.852, \mathrm{p}<0,01$ (1-tailed); Wilks ' $\Lambda=0,865$, parsial $\rceil 2=0,135)$, signifikan pada $\mathrm{p}=$ 0,000-0,006)

\section{PEMBAHASAN}

Kecanduan internet cenderung meningkat di negara-negara berkembang terutama di Negara 
Asia seperti China dan India, hal ini dikarenakan jumlah penduduk Negara yang tinggi dan tidak adanya filtrasi internet dengan baik yang dilakukan oleh pemerintah di negara tersebut, bahkan internet bisa menjangkau tempat-tempat terpencil yang ada di sana. (Krishnamurthy and Chetlapalli, 2015), menyatakan adanya kerentanan terhadap kecanduan internet pada mahasiswa yang berada di India. Berbeda dengan yang terjadi di negara-negara maju, prevalensi kecanduan internet tidak seekstrim yang terjadi di negara berkembang, dikarenakan pemerintah pada negara tersebut sudah mulai sadar akan bahaya internet sehingga dapat memfilter dan mengkontrol penggunaan internet.

Pada artikel yang telah direview, terdapat dampak negatif yang timbul akibat kecanduan gadget dan internet. Dampak yang timbul baik secara fisik maupun psikologi. Dampak secara fisik seperti obesitas, dikarenakan teknologi yang semakin canggih mempermudah seseorang dalam melakukan segala hal yang dapat menimbulkan kurangnya aktivitas fisik, sehingga beresiko mengalami obesitas. Penelitian yang dilakukan oleh menjelaskan kaitan antara kecanduan internet dan obesitas pada anak usia sekolah. Hasil dari penelitian tersebut menjelaskan bahwa anak dengan intensitas penggunaan gadget yang tinggi lebih beresiko 2,1 kali lebih besar untuk mengalami obesitas.

Dampak psikologi akibat kecanduan gadget dan internet, dari artikel yang telah didapat terdapat beberapa dampak seperti depresi, kesepian, gangguan pola tidur, gangguan pemusatan perhatian dan hiperaktif dan terganggunya fungsi keluarga.

Depresi bisa menjadisalah satu pemicu seseorang mengalami kecanduan internet, juga dapat menjadi dampak dari kecanduan internet. orang yang mengalami depresi biasanya sering merasa putus asa dan internet menjadi pelarian atas masalah yang mereka hadapi di dunia nyata. Semakin sering intensitas orang dengan internetmaka akan berkurang pula aktivitas dan komunikasi terhadap orang sekitar di kehidupan nyatanya. Akibat dari perilaku ini seseorang cenderung beresiko mengalami gangguan mental diantaranya depresi dan bunuh diri. Penelitian yang dilakukan oleh Indra (2019) menunjukkan hasil dari 171 responden yang mayoritas adalah perempuan $(63,2 \%)$ dengan rentan usia 14-17 tahun, sebanyak 120 pelajar $(70,2 \%)$ mengalami kecanduan internet sedangkan 55 (32,2\%) mengalami depresi. Terdapat hubungan antara kecanduan internet dan depresi pada siswa.

Dampak lain adalah kesepian. Kesepian menjadi salah satu dampak yang dipengaruhi oleh kecanduan internet. Hasil penelitian (Latief and Retnowati, 2018) menunjukkan bahwa dari 377 orang remaja SMA di Kota Yogyakarta berusia 15-17 tahun, kesepian dan harga diri dapat menjadi prediktor terhadap kecanduan internet pada remaja. Ketika seseorang mengalami kecanduan internet maka akan menggangu kehidupan sehari-hari orang tersebut, seperti tidak bisa menyesuaikan diri dengan lingkungan, terhambatnya komunikasi pada orangorang sekitar. Penggunaan internet pada orang yang merasakan kesepian merupakan tempat mendapatkan apa yang tidak mereka dapatkan dikehidupan nyata. Gangguan pola tidur dapat dipengaruhi oleh faktor internal seperti penyakit dan faktor eksternal seperti lingkungan. Penggunaan teknologi yang meningkat juga dapat menimbulkan efek samping yang buruk bagi tubuh seperti gangguan pola tidur. Penelitian yang dilakukan oleh Kasim (2018), menjelaskan bahwa internet merupakan sarana untuk mengatasi stress akademik yang berakibat pada terganggunya pola tidur mahasiwa tersebut. Hasil dari penelitian ini terdapat pengaruh tidak langsung antara stress akademik dengan kualitas tidur melalui kecanduan internet. Penelitian oleh (Nurdilla and Elita, 2018) hal ini dikarenakan orang yang menderita kecanduan akan melakukan aktivitas sama secara berulang dan terus menerus tanpa memikirkan waktu dan 
lingkungan sekitar.

Gangguan pemusatan perhatian dan hiperaktif (GPPH) biasanya berdampak pada kerja memori menjadi lemah. Anak yang bermain video game ataupun internet, dapat meningkatkan fungsi visual yang lebih aktif dan bisa menyebabkan hiperaktif. Kecanduan Gadget dapat mempengaruhi perkembangan otak anak karena produksi hormon dopamine yang berlebihan menganggu kematangan fungsi prefrontal korteks yaitu mengontrol emosi, kontrol diri, tanggung jawab, pengambilan keputusan dan nilai-nilai moral lainnya. Penelitian yang dilakukan oleh (Setianingsih, 2018) menunjukkan hasil antara kecanduan gadget dan kaitannya dengan GPPH. Hasil penelitian terdapat $81,1 \%$ anak menggunakan gadget $<2$ jam perhari dan $82,2 \%$ anak normal dan tidak memeiliki resiko GPPH. Nilai signifikansi adalah $\mathrm{p}=0,000$ sehingga $\mathrm{p}<\alpha(\alpha=0,05)$. Dampak lain dari kecanduan internet selain secara fisik dan psikologi yaitu terganggunya fungsi keluarga. Orang yang sering menggunakan gadget cenderung mengalami hambatan interaksi sosial dengan lingkungan sekitar. Pada penggunaan gadget akan terjadi perubahan interaksi antara orang tua dan anak, biasanya orang tua melakukan interaksi secara tatap muka akan tetapi dengan adanya gadget maka kini berganti dengan interaksi melalui gadget, hal ini menggangu fungsi keluarga dari aspek komunikasi. Perubahan pola komunikasi dan interaksi sosial yang dilakukan dalam keluraga tersebut akan berdampak pada sikap yang individualis. Penelitian Lestari (2015) menunjukan hasil bahwa terdapat perbedaan komunikasi antara sebelum dan sesudah menggunakan gadget pada anggota keluarga dalam polainteraksi.

\section{KESIMPULAN}

Dari 14artikel yang didapat, rata-rata penelitian dilakuakan pada remaja. Enam artikel yang membahas prevalensi kecanduan internet 2 diantaranya terjadi di negara maju seperti Jepang dan Taiwan, dari kedua negara tersebut prevalensi kecanduan internet rata-rata sebesar 22,6\%.Prevalensi pada negara berkembang seperti Turki, Tunisia, China dan India rata-rata sebesar32,3\%. Delapan artikel mengulas tentang dampak dari kecanduan internet. Terdapat dampak secara fisik (obesitas) dan psikologi (depresi, kesepian, bunuh diri, gangguan pola tidur, gangguan pemusatan perhatian dan hiperaktif) serta dampak lain seperti gangguan fungsi keluarga

\section{DAFTAR PUSTAKA}

Bhandari, P.M., Neupane, D., Rijal, S., Thapa, K., Mishra, S.R., Poudyal, A.K., 2017a. Sleep quality, internet addiction and depressive symptoms among undergraduate students in Nepal. BMC Psychiatry 17. https://doi.org/10.1186/s12888017-1275-5

Chasanah, A.M., Kilis, G., 2018b. Adolescents' Gadget Addiction and Family Functioning, in: Proceedings of the Universitas Indonesia International Psychology Symposium for Undergraduate Research (UIPSUR 2017). Presented at the Universitas Indonesia International Psychology Symposium for Undergraduate Research (UIPSUR 2017), Atlantis Press, Depok, Indonesia. https://doi. org/10.2991/uipsur-17.2018.52

Diarti, E., Sutriningsih, A., 2017. Hubungan Antara Penggunaan Internet Dengan Gangguan Pola Tidur Pada Mahasiswa Psik Unitri Malang. Nursing News 2, 11.

Eliacik, K., Bolat, N., Koçyiğit, C., Kanik, A., Selkie, E., Yilmaz, H., Catli, G., Dundar, N.O., Dundar, B.N., 2016b. Internet addiction, sleep and health-related life quality among obese individuals: a comparison study of the growing problems in adolescent health. Eating and Weight Disorders - Studies on Anorexia, Bulimia and Obesity 21, 709-717. https://doi.org/10.1007/ s40519-016-0327-z

Gunay, O., Ozturk, A., Ergun Arslantas, E., Sevinc, N., 2018b. Internet addiction and depression levels in Erciyes University students. Dusunen Adam: The Journal of Psychiatry and Neurological Sciences 31, 79-88. https://doi. org/10.5350/DAJPN2018310108

Kawabe, K., Horiuchi, F., Ochi, M., Oka, Y., 
Ueno, S., 2016. Internet addiction: Prevalence and relation with mental states in adolescents: Internet addiction in adolescents. Psychiatry and Clinical Neurosciences 70, 405-412. https://doi. org/10.1111/pcn.12402

Krishnamurthy, S., Chetlapalli, S.K., 2015. Internet addiction: Prevalence and risk factors: A crosssectional study among college students in Bengaluru, the Silicon Valley of India. Indian Journal of Public Health 59, 115. https://doi. org/10.4103/0019-557X.157531

Latief, N.S.A., Retnowati, E., 2018. Kesepian Dan Harga Diri Sebagai Prediksi Dari Kecanduan Internet Pada Remaja. Jurnal Ecopsy 5. https:// doi.org/10.20527/ecopsy.v5i3.5593

Lau, J.T.F., Gross, D.L., Wu, A.M.S., Cheng, K., Lau, M.M.C., 2017. Incidence and predictive factors of Internet addiction among Chinese secondary school students in Hong Kong: a longitudinal study. Social Psychiatry and Psychiatric Epidemiology 52, 657-667. https:// doi.org/10.1007/s00127-017-1356-2

Maulida, R., Sari, H., 2017. Kaitan Internet Addiction Dan Pola Tidur Pada Mahasiswa Fakultas Keperawatan 8.

Mellouli, M., Zammit, N., Limam, M., Elghardallou, M., Mtiraoui, A., Ajmi, T., Zedini, C., 2017. Prevalence and Predictors of Internet Addiction among College Students in Sousse, Tunisia 7.

Nurdilla, N., Elita, V., 2018. Hubungan Kecanduan Bermain Game Online Dengan Kualitas Tidur Remaja 5, 7.

Pan, P.-Y., Yeh, C.-B., 2018a. Internet Addiction among Adolescents May Predict Self-Harm/ Suicidal Behavior: A Prospective Study. The Journal of Pediatrics 197, 262-267. https://doi. org/10.1016/j.jpeds.2018.01.046

Panagiotidi, M., Overton, P., 2018b. The relationship between internet addiction, attention deficit hyperactivity symptoms and online activities in adults. Comprehensive Psychiatry 87, 7-11. https://doi.org/10.1016/j. comppsych.2018.08.004

Parashkouh, N.N., Mirhadian, L., EmamiSigaroudi, A., Leili, E.K., Karimi, H., 2018. Addiction to the Internet and mobile phones and its relationship with loneliness in Iranian adolescents. International Journal of Adolescent Medicine and Health 0. https://doi.org/10.1515/ ijamh-2018-0035
S. C., R., S., U., 2017a. Prevalence and pattern of internet addiction among medical students, Bengaluru. International Journal Of Community Medicine And Public Health 4, 4680. https:// doi.org/10.18203/2394-6040.ijcmph20175350

Setianingsih, S., 2018. Dampak Penggunaan Gadget Pada Anak Usia Prasekolah Dapat Meningkatan Resiko Gangguan Pemusatan Perhatian Dan Hiperaktivitas. Gaster: Jurnal Kesehatan 16, 191-205. https://doi.org/10.30787/gaster. v16i2.297

Seyrek, S., Cop, E., Sinir, H., Ugurlu, M., Şenel, S., 2017a. Factors associated with Internet addiction: Cross-sectional study of Turkish adolescents. Pediatrics International 59, 218-222. https:// doi.org/10.1111/ped.13117

So, R., Makino, K., Fujiwara, M., Hirota, T., Ohcho, K., Ikeda, S., Tsubouchi, S., Inagaki, M., 2017b. The Prevalence of Internet Addiction Among a Japanese Adolescent Psychiatric Clinic Sample With Autism Spectrum Disorder and/ or Attention-Deficit Hyperactivity Disorder: A Cross-Sectional Study. Journal of Autism and Developmental Disorders 47, 2217-2224. https://doi.org/10.1007/s10803-017-3148-7

Wu, C.-Y., Lee, M.-B., Liao, S.-C., Ko, C.-H., 2019b. A nationwide survey of the prevalence and psychosocial correlates of internet addictive disorders in Taiwan. Journal of the Formosan Medical Association 118, 514-523. https://doi. org/10.1016/j.jfma.2018.10.022

Xin, M., Xing, J., Pengfei, W., Houru, L., Mengcheng, W., Hong, Z., 2018a. Online activities, prevalence of Internet addiction and risk factors related to family and school among adolescents in China. Addictive Behaviors Reports 7, 14-18. https://doi.org/10.1016/j.abrep.2017.10.003 